\title{
OPEM
}

www.opem.org

Oriental Pharmacy and Experimental Medicine 2008 8(3), 228-235

DOI 10.3742/OPEM.2008.8.3.228

\section{Estrogen activity of Silkworm (Bombyx mori) Pupa water extract and its fractions}

\author{
Jae-Sung Ryu ${ }^{1 \dagger}$, Gyeong-Jong Jo ${ }^{2 \dagger}$, Jung-woo Jin ${ }^{1}$, Hyo-Jung Yang ${ }^{1}$, Yong-Il Park ${ }^{3}$, Ye-Seul Na ${ }^{3}$, \\ Kyung-Su Nam ${ }^{4}$, Kyung-Soo Keum ${ }^{2}$ and Young-Kug Choo ${ }^{1, *}$
}

${ }^{1}$ Department of Biological Science, College of Natural Sciences, Wonkwang University, Iksan, Jeonbuk 570-749, Republic of Korea; ${ }^{2}$ Professional Graduate School of Oriental Medicine and Traditional Oriental Medicine Institute, Wonkwang University, Iksan, Jeonbuk 570-749, Republic of Korea; ${ }^{3}$ Department of Biotechnology and The Biomaterial Engineering Research Center, The Catholic University of Korea, Bucheon, Gyeonggi-do 420743, Republic of Korea; ${ }^{4}$ Bogo F\&D, 936 Jinmiparagon, 13 Yeouido-dong, Yeongdeungpo-gu, Seoul 150-870, Republic of Korea

Received for publication July 16, 2008; accepted August 01, 2008

\begin{abstract}
SUMMARY
This study was conducted to evaluate the estrogen activity of silkworm (Bombyx mori) pupa extracts and their fractions. Powdered samples of freeze-dried silkworm pupa were extracted at room temperature $(\mathrm{RT}), 40^{\circ} \mathrm{C}, 60^{\circ} \mathrm{C}, 80^{\circ} \mathrm{C}$, and $100^{\circ} \mathrm{C}$ in water (D.W), chloroform, ethyl acetate, and methanol for $6 \mathrm{~h}$ and then filtered $(0.45 \mathrm{um})$. The extracts were then freeze-dried. The estrogenic activity of these extracts was then investigated by competition binding assays using estrogen receptor $\alpha(E R \alpha)$ and $E R \beta$, and by evaluating their effects on the proliferation of the human breast cancer cell line, MCF-7. Among the extracts evaluated, water extracts prepared at RT showed the highest binding affinity to $\mathrm{ER} \alpha\left(\mathrm{IC}_{50}, 1.76 \mathrm{ug} / \mathrm{ml}\right)$ and $\mathrm{ER} \beta\left(\mathrm{IC}_{50}\right.$, $0.07 \mathrm{ug} / \mathrm{ml})$. In addition, MCF-7 cells that were treated with $62.5 \mathrm{ug} / \mathrm{ml}$ of the RT extract showed the greatest increase in proliferation (2-fold; $1291.79 \%$ ) when compared to control cells $(659.82 \%)$. Next, the water extract that was prepared at RT (sample 1) was dissolved in D.W. and further fractionated using a Dowex 50W - 8X $\left(\mathrm{H}^{+}\right)$column. The flow-through and wash were then pooled together and freeze-dried (sample 2). The bound materials were then eluted with $20 \mathrm{mM} \mathrm{NaCl}$, after which they were applied to a Dowex 1X2 - $200\left(\mathrm{Cl}^{-}\right)$column and washed with D.W. to remove the sodium ions. The eluants were then freeze-dried (sample 3 ). Of these fractions, sample 2 showed the highest binding affinity to ER $\alpha\left(\mathrm{IC}_{50}, 1.44 \mathrm{ug} / \mathrm{ml}\right)$ and $\operatorname{ER} \beta\left(\mathrm{IC}_{50}, 1.18 \mathrm{ug} / \mathrm{ml}\right)$. In addition, MCF-7 cells that were treated with sample $2(15.6 \mathrm{ug} / \mathrm{ml})$ showed the largest increase in growth (1159.39\%) when compared to control cells $(525.26 \%)$. Taken together, these results suggest that the fraction of the RT water extract of silkworm pupa referred to as sample 2 may be useful as a phytoestrogen.
\end{abstract}

Key words: Silkworm pupa water extract; Estrogen; Estrogen receptor; MCF-7 cells

\footnotetext{
*Correspondence: Young-Kug Choo, Department of Biological Science, College of Natural Sciences, Wonkwang University, 344-2 Shinyong-dong, Iksan, Jeonbuk, 570-749, Republic of Korea. Tel: +82638506087; Fax: +82638578837; E-mail: ykchoo@wonkwang.ac.kr

${ }^{\dagger}$ These authors contributed equally to this work.
} 


\section{INTRODUCTION}

Estrogens, which are named for their importance in the estrous cycle, are a group of steroid hormones that are secreted from the ovaries and function as the primary female sex hormone. As such, estrogens play a prominent role in regulation of the maturation, proliferation, and differentiation of the mammary gland, and influence the growth and development of breast cancer (Yager, 2000). Estrogen is also a major hormone involved in the proliferation and differentiation of cells in various target organs. The biological activity of estrogen is primarily mediated through estrogen receptors (ER), which belong to the superfamily of steroid transcription factors (Farooqui et al., 2006). Estrogen receptor $\alpha(E R \alpha)$ and $E R \beta$ are distinct gene products that can be expressed at different levels in the same tissue or in different tissues (Hall et al., 2001; Nilsson and Gustafsson, 2002). ER $\alpha$ is the dominant species expressed in the uterus, liver, adipose tissue, skeletal muscle, the pituitary and hypothalamus, whereas ER $\beta$ is the major form expressed in the ovaries, testis and the prostate, as well as in some regions, of the brain regions including the limbic system, cerebellum and cerebral cortex (Ruff et al., 2000). ER $\alpha$ and ER $\beta$ are co-expressed in breast tissue, the urogenital tract, bone and the cardiovascular system within the same cell-types, as well as in different cell populations (Nilsson and Gustafsson, 2002).

Previous studies have shown that dong quai and ginseng (Amato et al., 2002), soy and red clover (Bodinet and Freudenstein, 2004), and legumes (Boué et al., 2003) have estrogenic activity. Furthermore, Ruff et al. (2000) reported that phytoestrogen reduces cancer and hot flashes.

Therefore, in the present study, we evaluated the estrogen activity of silkworm pupa water extracts and their fractions using an 3-(4,5-dimethylthiazol2-yl)-2,5-diphenyltetrazolium bromide (MTT) assay to evaluate the effects of the fractions on the proliferation of MCF-7 human breast cancer cells.
In addition, we evaluated the binding activity of the extracts and their fractions using an ER binding competition assay.

\section{MATERIALS AND METHODS}

\section{Preparation of extracts and of silkworm pupa and fractionation}

Silkworm pupa was purchased from the Korean Society of Sericultural Science (Suwon, Republic of Korea). Silkworm pupa were then extracted at room temperature (RT), $40^{\circ} \mathrm{C}, 60^{\circ} \mathrm{C}, 80^{\circ} \mathrm{C}$, and $100{ }^{\circ} \mathrm{C}$ in distilled water (D.W.), chloroform, ethyl acetate, and methanol for $6 \mathrm{~h}$, after which they were filtered $(0.45 \mathrm{um})$. The extracts were then freeze-dried and evaluated for their effects on proliferation and ER binding as described below. The sample with the greatest effect was then dissolved in D.W. and further fractionated through a Dowex 50W - 8X $\left(\mathrm{H}^{+}\right)$column. The flow-through and D.W. wash were pooled together and freezedried. The bound materials were then eluted with $20 \mathrm{mM} \mathrm{NaCl}$. Next, the eluants were applied to a Dowex 1X2 - $200\left(\mathrm{Cl}^{-}\right)$column and washed with D.W. to remove the sodium ions. The eluants were then freeze-dried and used for further analysis.

\section{Cell culture}

Human breast cancer MCF-7 cells were cultured in Dulbecco's modified Eagle's Medium (DMEM; Sigma, St. Louis, MO) supplemented with $1 \%$ antibiotic-antimycotic (10,000 unit/ml, Gibco BRL, Grand Island, NY) and 10\% heat-inactivated charcoal/dextran treated fetal bovine serum (FBS; Hyclone, Logan, UT) at $37^{\circ} \mathrm{C}$ under $5 \% \mathrm{CO}_{2}$ in a humidified cell incubator.

\section{Immunofluorescence assay}

MCF-7 cells were permeabilized with $0.25 \%$ Triton $\mathrm{X}-100$ for 10mins at room temperature, after which they were fixed with $4 \%$ paraformaldehyde in phosphate-buffered saline (PBS) for $15 \mathrm{~min}$ at room temperature. The fixed cells were then blocked for 
20 min with PBS containing 5\% bovine serum albumin (BSA). Next, the cells were then incubated for $16 \mathrm{~h}$ at $4{ }^{\circ} \mathrm{C}$ with mixtures containing primary antibodies specific to ER $\alpha$ and ER $\beta$ (Santa Cruz Biotechnology, Inc., Santa Cruz, CA) in PBS containing $1 \%$ BSA. Secondary antibody conjugated to fluorescent goat and anti-mouse IgG conjugated to FITC (Sigma, St Louis, MO) were applied at dilutions of 1: 500 and 1: 800, respectively. Next, the cells were washed with PBS, after which they were observed under a confocal microscope (Model FV300, Olympus, Japan).

\section{MTT assay}

Human breast cancer MCF-7 cells were seeded at a density of $5 \times 10^{3}$ cells/well in 24-well plates. The cells were then treated with the silkworm pupa water extracts and their fractions at concentrations of $250 \mathrm{ug} / \mathrm{ml}, 62.5 \mathrm{ug} / \mathrm{ml}, 15.6 \mathrm{ug} / \mathrm{ml}$, and $3.9 \mathrm{ug} /$ $\mathrm{ml}$ for $24 \mathrm{~h}, 48 \mathrm{~h}, 72 \mathrm{~h}$, and $96 \mathrm{~h}$, after which the cell proliferation was determined by a MTT assay. Briefly, each well was incubated in MTT (Sigma, St. Louis, MO) solution for $4 \mathrm{~h}$, and the absorbance of each well at $490 \mathrm{~nm}$ was then determined using a spectrophotometer.

\section{Competition ER binding assay}

ER binding was performed using an ER $(\alpha, \beta)$ competitor assay red kit (Pan Vera, Madison, WI). Briefly, the silkworm pupa extract and their fractions were diluted to a concentration of $2 X$ in ER Red assay buffer. Serial dilutions of the $2 X$ solution were then made so the $\mathrm{IC}_{50}$ could be determined. Next, a 2X ER/Fluormone EL Red Complex containing $\mathrm{ER} \alpha$ at a final concentration of $30 \mathrm{nM}$ or ER $\beta$ at a final concentration of $60 \mathrm{nM}$ and $2 \mathrm{nM}$ Fluormone EL Red in ER red assay buffer was prepared. Twenty microliters of the diluted $2 X$ test compounds were then added to each well, after which $20 \mathrm{ul}$ of the $2 X$ ER/Fluormone EL Red Complex was added. The solutions in the wells were then mixed, after which the plate was covered and incubated in the dark at room temperature for $1-18 \mathrm{~h}$. The absorbance of each well at $535 \mathrm{~nm}$ excitation and $590 \mathrm{~nm}$ emission was then measured.

\section{Statistical analysis}

All data are presented as the mean \pm S.D. The groups were compared using two-way ANOVA followed by Tukey's test for multiple comparisons. All statistical analyses were performed using Graphpad Prism version 5 (Graphpad software, San Diego, CA)

\section{RESULTS}

\section{Immunofluorescence staining of MCF-7 cells}

We first examined the expression of ER $\alpha$ and ERâ in the human breast cancer cell line, MCF-7. Briefly, the presence of ER $\alpha$ and ER $\beta$ was determined by immunofluorescence staining using monoclonal ER $\alpha$ and ER $\beta$ antibodies. As shown in Fig. 1, ER $\alpha$ and ER $\beta$ was localized to the MCF-7 cells.

\section{Effect of ER binding in response to treatment with the water extract of silkworm pupa}

To evaluate the affinity binding to ER, the effects of the 8 compounds on the binding affinities were evaluated. The resulting competitive binding curves were then analyzed using the PRISM software (Ver. 5.0; GraphPad Software Inc., USA) to assess the potency of the competitor molecule. The concentration that inhibited $50 \%$ (i.e. the $\mathrm{IC}_{50}$ value) of each test compound was then determined by nonlinear least-squares regression (Table 1). The binding affinity of RT water extract (ER $\alpha ; 1.76 \pm$ 0.13 , ER $\beta ; 0.07 \pm 0.06$ ) was found to be higher than that of 17 $\beta$-estradiol (E2) $(\mathrm{ER} \alpha ; 8.37 \pm 0.05$, ER $\beta$; $0.19 \pm 0.05)$. These results suggest that water extract of silkworm pupa can bind to ER.

\section{Effect of the extract of silkworm pupa on the proliferation of MCF-7 cells}

Next, the proliferation effect of silkworm pupa extracts prepared at $\mathrm{RT}, 40^{\circ} \mathrm{C}, 60^{\circ} \mathrm{C}, 80^{\circ} \mathrm{C}$ and $100^{\circ} \mathrm{C}$ in water, chloroform, ethyl acetate, and methanol 

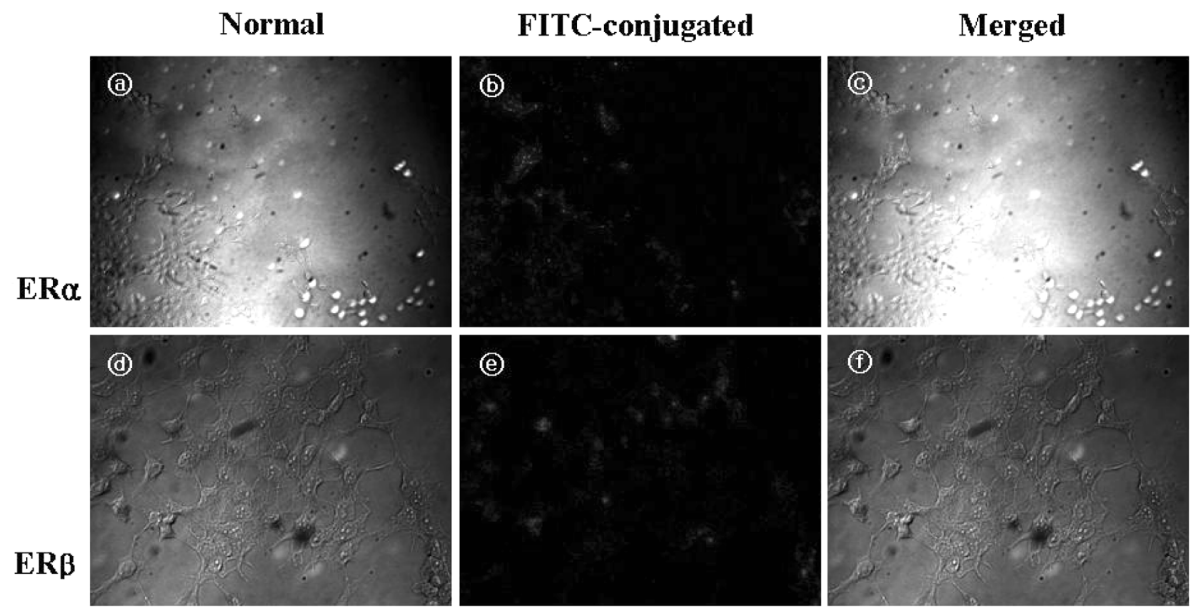

Fig. 1. Immunofluorescence staining of estrogen receptor $\alpha(E R \alpha)$ and $E R \beta$ expressed in MCF-7 cells. Cells were immunostained with anti-ER $\alpha$ and ER $\beta$ Mab (primary), and FITC-conjugated goat anti-mouse IgG Mab (secondary) and then observed using laser scaning confocal microscopy. Panel: (a,b and c), ER $\alpha$; (d, e and f), ER $\beta$; (a and d), normal; (b and e), ER $\alpha$ and ER $\beta$; (e and f) merged.

Table 1. $\mathrm{IC}_{50}$ value of ER binding of silkworm pupa water extracts

\begin{tabular}{lrc}
\hline \multirow{2}{*}{ Sample Name } & \multicolumn{2}{c}{$\mathrm{IC}_{50}(\mathrm{ug} / \mathrm{ml})^{1)}$} \\
\cline { 2 - 3 } & \multicolumn{1}{c}{$\mathrm{ER} \alpha$} & $\mathrm{ER} \beta$ \\
\hline $\mathrm{E} 2$ & $8.37 \pm 0.05$ & $0.19 \pm 0.05$ \\
$100^{\circ} \mathrm{C}$ & $9.82 \pm 0.12$ & $0.14 \pm 0.09$ \\
$80^{\circ} \mathrm{C}$ & $10.27 \pm 0.06$ & $0.26 \pm 0.07$ \\
$60^{\circ} \mathrm{C}$ & $4.17 \pm 0.05$ & $0.09 \pm 0.01$ \\
$40^{\circ} \mathrm{C}$ & $8.91 \pm 0.06$ & $0.26 \pm 0.07$ \\
$\mathrm{RT}$ & $1.76 \pm 0.13$ & $0.07 \pm 0.06$ \\
$\mathrm{Chloroform}$ & $6.92 \pm 0.13$ & $0.16 \pm 0.14$ \\
Ethyl acetate & $6.30 \pm 0.07$ & $0.19 \pm 0.06$ \\
Methanol & $7.82 \pm 0.9$ & $0.32 \pm 0.06$ \\
\hline
\end{tabular}

ER competition data was generated from 384-well plates using an ELISA reader. The concentration of test compounds resulting in a half-maximal shift in polarization value equals its $\mathrm{IC}_{50}$. Each value is expressed as the mean \pm S.D. in triplicate experiments. ${ }^{1)}$ The $\mathrm{IC}_{50}$ value is the concentration of sample required for $50 \%$ inhibition.

on the proliferation of MCF-7 cells was evaluated. To accomplish this, the cells were cultured with the extracts of silkworm pupa at final concentrations of $250 \mathrm{ug} / \mathrm{ml}, 62.5 \mathrm{ug} / \mathrm{ml}, 15.6 \mathrm{ug} / \mathrm{ml}$, and $3.9 \mathrm{ug} / \mathrm{ml}$ for $24 \mathrm{~h}, 48 \mathrm{~h}, 72 \mathrm{~h}$, and $96 \mathrm{~h}$, after which MTT assays were conducted (Fig. 2). Cells that were cultured in silkworm pupa-free media and cells that were treated with $17 \beta$-estradiol were used as negative and positive controls, respectively. The greatest increase in cell proliferation occurred in response to treatment with the RT extract for $96 \mathrm{~h}$ $(1291.79 \pm 37.1 \%$, concentration $62.5 \mathrm{ug} / \mathrm{ml})$ when compared to increase in the control cells (659.82 \pm $48.7 \%$ ) (Fig. 2B).

These results demonstrated that the water extract of silkworm pupa induced the greatest increase in cell proliferation. However, treatment with fat soluble (chloroform, ethyl acetate, and methanol) extracts of silkworm reduced cell proliferation. Based on these results, the RT water extract was used for the next experiment.

\section{The ability of the RT water extract of silkworm pupa to bind to ER}

In a previous study, we demonstrated that RT water extracts of silkworm pupa had the potential for use as potential phytoestrogens. Therefore, to assess the effects of the individual fractions of RT water extracts of silkworm pupa, the initial RT extract (sample 1) was dissolved in D.W. and further fractionated by passing it through a Dowex $50 \mathrm{~W}-8 \mathrm{X}\left(\mathrm{H}^{+}\right)$column. The flow-through and D.W. wash were pooled together and freeze-dried 

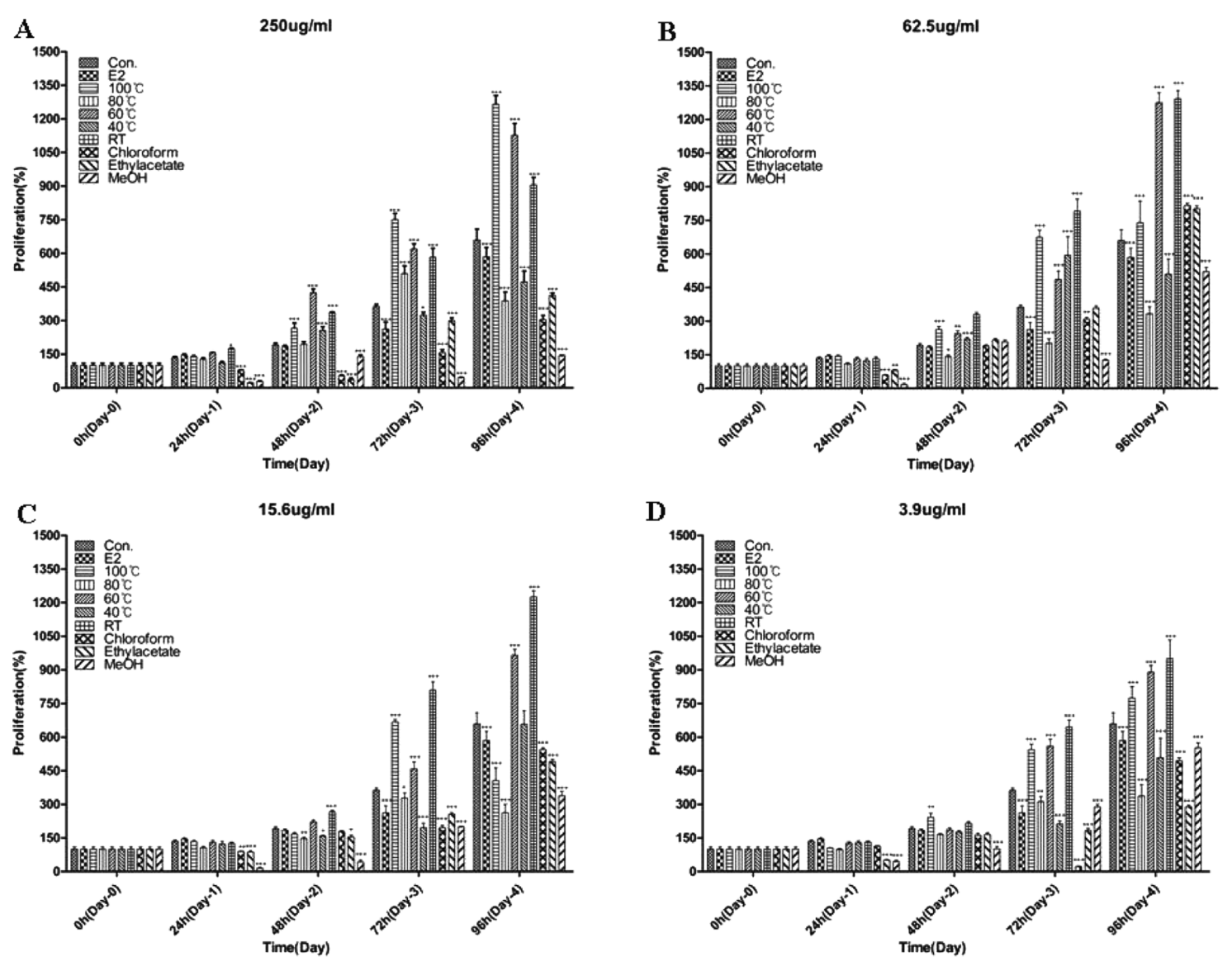

Fig. 2. Effect of silkworm (bombyx mori) pupa water extracts on the proliferation of MCF-7 human breast cancer cells, in vitro. MCF-7 cells $\left(5 \times 10^{3}\right.$ cells/well in 24 -well plates) were treated with silkworm pupa extracted at room temperature $(\mathrm{RT})\left(\right.$ 曲), $40^{\circ} \mathrm{C}(\mathbb{\mathrm { N }}), 60^{\circ} \mathrm{C}(\mathbb{\Delta}), 80^{\circ} \mathrm{C}(\mathrm{m})$, and $100^{\circ} \mathrm{C}($ 目) in water, chloroform (国), ethyl acetate $(\mathbb{\nabla})$, and methanol ( $\triangle \Delta$ ) at concentrations of (A) $250 \mathrm{ug} / \mathrm{ml},(B) 62.5 \mathrm{ug} / \mathrm{ml},(\mathrm{C}) 15.65 \mathrm{ug} / \mathrm{ml}$ and (D) $3.90 \mathrm{ug} / \mathrm{ml}$ for $24 \mathrm{~h}, 48 \mathrm{~h}, 72 \mathrm{~h}$ and $96 \mathrm{~h}$. Data are presented as the mean \pm S.D. of six separate experiments. Sample groups were compared using 2 way ANOVA. Con. vs. ${ }^{*} P<0.05$, Con. vs. ${ }^{* *} P<0.01$, Con. vs. ${ }^{* *} P<0.001$.

(sample 2). The bound materials were then eluted with $20 \mathrm{mM} \mathrm{NaCl}$, after which they were applied to a Dowex $1 \mathrm{X} 2-200(\mathrm{Cl})$ column and washed with D.W. to remove the sodium ions. The eluants were then freeze-dried (sample 3).

Next, the binding affinities of the 3 compounds were determined. The binding affinity of sample 2 $(\mathrm{ER} \alpha ; 1.44 \pm 0.05, \mathrm{ER} \beta ; 1.18 \pm 0.06)$ was found to be greater than that of $\mathrm{E} 2(\mathrm{ER} \alpha ; 8.37 \pm 0.05, \mathrm{ER} \beta ; 1.66 \pm$ 0.05 ) (Table 2). Taken together, these results suggest that the individual fractions of silkworm pupa water extract, specifically sample 2 , could bind to $E R$, which indicates that it had estrogenic effects.
Table 2. $\mathrm{IC}_{50}$ value of ER binding of fractions of silkworm pupa water extracts

\begin{tabular}{lcc}
\hline \multirow{2}{*}{ Sample Name } & \multicolumn{2}{c}{$\mathrm{IC}_{50}(\mathrm{ug} / \mathrm{ml})^{1)}$} \\
\cline { 2 - 3 } & $\mathrm{ER} \alpha$ & $\mathrm{ER} \beta$ \\
\hline E2 & $8.37 \pm 0.05$ & $1.66 \pm 0.05$ \\
Sample 1 & $2.58 \pm 0.05$ & $1.21 \pm 0.06$ \\
Sample 2 & $1.44 \pm 0.05$ & $1.18 \pm 0.06$ \\
Sample 3 & $4.77 \pm 0.05$ & $1.35 \pm 0.05$ \\
\hline
\end{tabular}

ER competition data was generated from 384-well plates using an ELISA reader. The concentration of test compound resulting in a half-maximal shift in polarization value equals its $\mathrm{IC}_{50}$. Each value is expressed as the mean \pm S.D. of triplicate experiments. 1) The $\mathrm{IC}_{50}$ value is the concentration of the sample required for $50 \%$ inhibition. 
A

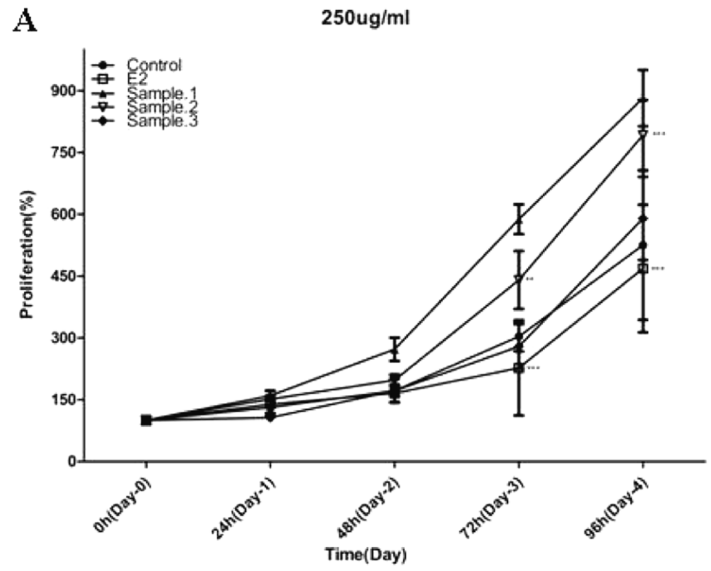

C

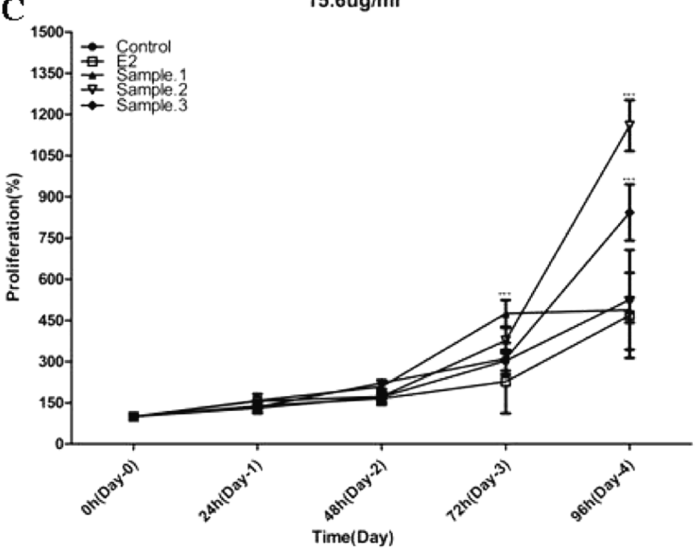

B

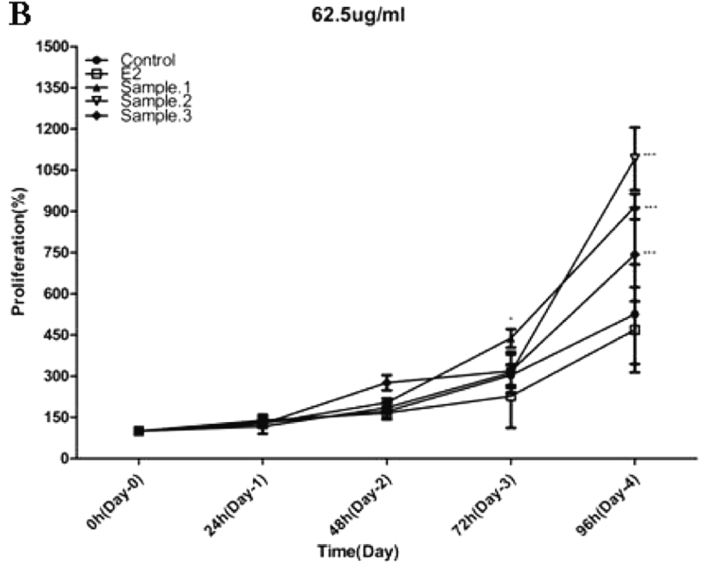

D

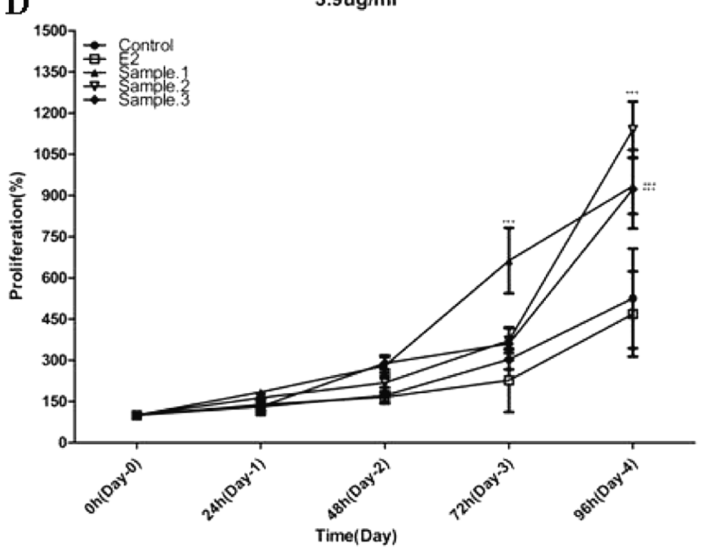

Fig. 3. Effect of fractions of silkworm (bombyx mori) pupa water extracts on the proliferation of MCF-7 human breast cancer cells in vitro. MCF-7 cells $\left(5 \times 10^{3}\right.$ cells/well in 24-well plates) were treated with silkworm pupa water extracted at RT, sample $1(\boldsymbol{\Delta})$, sample $2(\nabla)$, and sample $3(\bullet)$ at concentrations of (A) $250 \mathrm{ug} / \mathrm{ml},(\mathrm{B})$ $62.5 \mathrm{ug} / \mathrm{ml}$, (C) $15.65 \mathrm{ug} / \mathrm{ml}$ and (D) $3.90 \mathrm{ug} / \mathrm{ml}$ for $24 \mathrm{~h}, 48 \mathrm{~h}, 72 \mathrm{~h}$ and $96 \mathrm{~h}$. Data are presented as the mean \pm S.D. of six separate experiments. Treatment groups were compared by 2 way ANOVA. Con. vs. ${ }^{*} P<0.05$, Con. vs. ${ }^{2} P<$ 0.001 .

\section{Effect of the fractions of RT water extract of silkworm pupa on the proliferation of MCF-7 cells}

MCF7 cells were cultured with the RT water extract of the silkworm pupa and its fractions at final concentrations of $250 \mathrm{ug} / \mathrm{ml}, 62.5 \mathrm{ug} / \mathrm{ml}, 15.6$ $\mathrm{ug} / \mathrm{ml}$ and $3.9 \mathrm{ug} / \mathrm{ml}$ for $24 \mathrm{~h}, 48 \mathrm{~h}, 72 \mathrm{~h}$ and $96 \mathrm{~h}$, after which MTT assays were conducted (Fig. 3). The results revealed that sample 2 induced the greatest increase in growth (2-fold $(1159.39 \%)$ at a concentration of $15.6 \mathrm{ug} / \mathrm{ml}$ ), when compared to that of the control (525.26\%) (Fig. 3B). Taken together, these results demonstrate that sample 2 of the silkworm pupa water extracts induced cell proliferation.

\section{DISCUSSION}

Silkworm pupa (bombyx mori) is a traditional Asian medicine that reportedly has antimycotic (Madana Mohana et al., 2007), antijuvenoid (Saha et al., 2007), and antioxidant effects, as well as the ability to improve lipid metabolism (Kwon et al., 2006) prevent the proliferation of cancer (Lim et al., 2007), and function as an osteoblast (Choi et al., 2005). In the present study, we compared the effects of the water extract of silkworm pupa and its factions on estrogen activity in MCF-7 cells.

We found that, of the silkworm pupa extracts 
prepared, water extracts prepared at RT and its fractions had the greatest ability to bind ER. It has been suggested that elevation of estrogen binding is associated with the functional relationship of DNA- and the ligand- binding domains of ER (Ruff et al., 2000).

In addition, we found that the silkworm pupa water extract prepared at RT and its fractions induced a 2-fold increase in the growth of MCF-7 cells, while extracts prepared using solutions that are fat soluble did not. These findings are similar to the results of a study conducted by Yang et al. (2005). Taken together, these findings suggest that estrogen induces the proliferation of MCF-7 cells via an ER and proliferation signaling pathway. Interestingly, in a previous study, the proliferation of MCF-7 cells and human prostate stromal cells induced by E2 were primarily mediated by HRG/ HER-2/PKC- $\delta /$ Ras/Raf/MEK/ERK (Venkateshar et al., 2002; Zhang et al., 2008).

In this study, we evaluated the binding affinities of silkworm pupa water extracts as well as their effects of MCF-7 cells. We found that water extracts prepared at RT and its fractions significantly bound to ER $\alpha$ and ER $\beta$. In addition, these extracts induced the growth of MCF-7 cells. These results suggest that silkworm pupa water extracts that were prepared at RT, particularly sample 2, may be useful as a phytoestrogen. However, further studies using menopausal animal models and chemical experiments are needed to elucidate the mechanism by which the extract exerts its estrogen activity.

\section{ACKNOWLEDGEMENTS}

This study was supported by a grant from the Korea Rural Development Administration (20080201033-015-001-01-00).

\section{REFERENCES}

Amato P, Christophe S, Mellon PL. (2002) Estrogenic activity of herbs commonly used as remedies for menopausal symptoms. Menopause 9, 145-150.

Atul Kumar Saha, Tapati Datta (Biswas), Salil Kumar Das, Niharendu Bikash Kar. (2007) Antijuvenoid action of terpenoid imidazole compound on larval pupal - adult development of skilworm, Bombyx mori L. Int. J. Indust. Entomol. 14, 127-135.

Bodinet C, Freudenstein J. (2004) Influence of marketed herbal menopause preparations on MCF-7 cell proliferation. Menopause 11, 281-289.

Boué SM, Wiese TE, Nehls S, Burow ME, Elliott S, Carter-Wientjes CH, Shih BY, McLachlan JA, Cleveland TE. (2003) Evaluation of the estrogenic effects of legume extracts containing phytoestrogens. J. Agric. Food Chem. 51, 2193-2199.

Kwon EH, Jung MA, Rhee SJ, Choi SW, Cho SH. (2006) Antioxidant effects and improvement of lipid metabolism of mulberry fruit, mulberry leaves and silkworm powder with different mixing ratios in streptozotocin-induceed diabetic rats. Korean J. Nut. 39, 91-99.

Choi EM, Lee KH, Koo SJ. (2005) Effect of silkworm (bombyx mori) pupa extract on the function of osteoblastic MC3T3-E1 cells. Food Sci. Biotechnol. 14, 593-598.

Farooqui M, Geng ZH, Stephenson EJ, Zaveri N, Yee D, Gupta K. (2006) Naloxone acts as an antagonist of estrogen receptor activity in MCF-7 cells. Mol. Cancer Ther. 5, 611-620.

Lim HY, Lim YE, Hong SW, Lee CH, Lim YH. (2007) Antiproliferative effect of silkworm extrat. J. Appl. Biol. chem. 50, 293-295.

Hall JM, Couse JF, Korach KS. (2001) The multifaceted mechanisms of estradiol and estrogen receptor signaling. J. Biol. Chem. 276, 36869-36872.

Yang JW, Choi EM, Kwon MG, Koo SJ. (2005) In vitro estrogenic activity of silkworm (Bombyx mori) pupa and herbs. J. East Asian Soc. Dietary Life. 15, 315-322.

Nilsson S, Gustafsson JA. (2002) Estrogen receptor action. Crit. Rev. Eukaryot. Gene Expr. 12, 237-257.

Madana Mohana N, Gupta SK, Mitra P. (2007) Antimycotic activity of Allum Sativum Against Beauveria Vassiana, pathogenic fungus of white muscardine disease in silkworm, Bombyx mori L. (Lepidoptera: Bombycidae). Int. J. Indust. Entomol. 14, 81-85.

Ruff M, Gangloff M, Wurtz JM, Moras D. (2000) Estrogen receptor transcription and transactivation: Structure-function relationship in DNA- and ligand- 
binding domains of estrogen receptor. Breast Cancer Res. 2, 353-359.

Venkateshwar G, Keshamouni, Raymond R, Mattingly, Kaladhar B Reddy. (2002) Mechanism of 17-Estradiolinduced Erk1/2 Activation in Breast Cancer Cells. J. Biol. Chem. 277, 22558-22565.

Yager JD. (2000) Endogenous estrogens as carcinogens through metabolic activation. J. Natl. Cancer Inst. Monographs 27, 67-73.

Zhang Z, Duan L, Du X, Ma H, Park I, Lee C, Zhang J, Shi J. (2008) The proliferative effect of estradiol on human prostate stromal cells is mediated through activation of ERK. Prostate 68, 508-516. 